\title{
CONSTRUCTING SELF AWARENESS USING EDUCATION HUMAN VALUE IN SCHOOL CULTURE
}

\author{
Dewa Nyoman Wija Astawa \\ IKIP Saraswati Tabanan \\ dw.wija@gmail.com
}

\begin{abstract}
The big number of poverty in Indonesia impact to the hope of having a free learning service, especially education for early age and elementary school students from the less fortunate families. Many people usually ask the quality of such kinds of free of charge schools. The low price makes a low standard for the students. Sathya Sai School in Denpasar has proven that the free learning service does not mean the standard quality of the school is low. This study will explain how the teachers and the members of the foundation build the awareness of the students and parents by socializing and internalizing the value that empower their collective awareness to help the school achievement. By using local cultural approach, the school builds a program that involves the parents especially the woman.
\end{abstract}

Key words: human value education, free-education, self-awareness

\section{A. Introduction}

The education for children in their early ages is fundamental to the children's development in the next years. The period is the golden time in life but comes only once. During the time, education, stimulation, counseling, maintaining, caring, will all help the potency of the children.

In those early ages there should start a process of self-awareness. Thus, the primary level of formal education, which includes the pre-school stage, is not only about understanding important formal lessons but also about implementing this self-awareness in language, cognitive, psychomotor, and creativity class acitivities.

The self-awareness is marked with physical claims and particular activities that challenge morals. ${ }^{1}$. Their ideals come from the material world around. The children identities are carefully develop from their social and psychological environment.

Modern society believes that self-awareness is one of the domains in the children development that demands attention. It is believed that the process of transferring things would be contributive. The awareness is a concept with which the children see themselves through different perspectives and know how to behave in accordance with their beliefs and the social norms. According to Catron ${ }^{2}$, children in their early ages need stable emotion as a form of self-awareness along with their physical growth. The self-awareness concept may be formed by internalizing self-reliance, sex-awareness, gender role, tolerance, and personal health care.

1 Darmadi, H. 2006. Dasar Konsep Pendidikan Moral: Landasan Konsep Dasar dan Implementasi. (Bandung: Alfabeta, 2006) p. 191

2 Catron, C.E. 2006. Early Childhood Curriculum: A Creative Play Model. Upper Saddle River, New Jersey: Pearson, 2006) p. 199-201 


\section{B. Research Methods}

This article discusses how education for children in their early ages is done with some construct that adjusts the background and environment of the children. With qualitative approach, the study was carried out at the Sathya Sai School in Denpasar, Bali, a school with its own characteristics. The data were collected through observation and FGD (focus group discussion) involving the teachers, the headmaster, the foundation members, and the students'parents. The analysis was done to the text resulting from the observation and FGD.

\section{Results and Discussion}

\section{The Profile of Sathya Sai School Denpasar}

The Sathya Sai School of Denpasar is located at jalan Kemuda III No. 9 Peguyangan Kangin, Northern Denpasar. It started with the establishment of kindergarten on the $12^{\text {th }}$ July 2002 and was inspired by the Sathya Sai School at India and around the world. The school applies EHV that centres on character building to prepare the students with discipline, social care, religious teachings, and hardworking.

The entrance test for the students includes interview with their parents, regarded as a kind of "contract" as so-called by Mr. I Ketut Wiana, the foundation chairman, between the school and the students'parents, in which the mission and vision of the school are introduced and to be understood by the parents. The interview is also the time when the commitment of the parents for their children education is emphasized as a bridge to strengthen the basis of EHV. This has been seen important as most of the students'time is spent with their parents. The interview is also a time for the foundation to show that the school program is based on truth, rightenousness, peace, love, and non-violence principles. The five become the characteristics of the school curriculum. Then, after five years, on the $12^{\text {th }}$ July 2007 , the school established its elementary school accredited A.

\section{The Implementation of EHV}

EHV comes from the combination of 3-H, i.e. head, heart, and hand. It suggests that any words delivered by the head and then spoken should be first screened by the heart, before finally being executed as action. EHV has a strategic role in developing quality human resources. The program of EHV at the elementary school purposed to provide the children with knowledge, attitude, moral, social skills, and services so that they can continue to study at the higher levels. The program expects individuals with good social attitudes and be able to solve problems found in their environment ${ }^{3}$.

The EHV at the Sathya Sai School in Denpasar was derived from the model developed by the Institute of Sathya Sai Education in India, which has been an adaptation of the one promoted by Dr. Art-Ong Jumsai Na Ayudhya of ISSE Thailand. The chairman of the Sathya Sai Indonesia Education, Mr. Anuraga Duarsa said that in Indonesia the development of EHV should consider the local cultures which include the religions and faiths that belong to the local people.

3 Wortham, S.C. Early Childhood Curriculum: Developmental Bases for Learning and Teaching. (Upper Sadle River, New Jersey: Pearson, 2006) p. 7 
EHV always involves social skills that pedagogically are not possible implemented through the conventional teaching. It requires optimal growth of the students, especially their service attitudes, which can never be taught without concrete practice. This means the program should facilitate the students'potencies optimally so that their studying becomes fully meaningful.

EHV at the Sathya Sai School is not merely aimed at the teachers and their students. The parents and the school assistants are also targeted. The end is to create a conducive surrounding for the whole community. Thus, a parenting program is scheduled for once a month. In addition, the teachers and the school employees are given a Personal Development (PD) program of which the material is given by invited speakers.

EHV, according to Na-Ayudhya, is developing as a stimulus for the 5 senses though it is not always understood properly since most information is stored in the subconscious mind. For children this condition might be bad or good. Consequently, the teachers should be able to integrate the important values to stimulate what are kept subconsciously ${ }^{4}$.

The most important part of EHV is inspiring the students for some transformation that emphasizes the balance of mind, words, and action. Thoughts should be controlled by the heart before becoming speech and action. The human values are not to be taught in words yet delivered through afirmation, habit, and inspiration at schools and homes. The values are truth, right conduct, peace, love, and non-violence and love is the core of all because it creates closeness. Action with love will change into mild attitudes which in turn become right conducts. When the five values are maintained the self realization or self awareness can be attained.

\section{Parenting: Developing the Parents' Care}

Parenting is an obliged monthly program for the students'parents. It is purposed to keep an effective communication about the school agenda, the needs of the parents and the community. With the program the parents are hoped to stimulate and begin the change. This is based on the fact that most of the time the children spend is with their parents.

With the material that is based on the need of the children, parenting is done to exercise critical mind towards collective consciousness, which is based on good education for the generation. Parents and teachers are like the two wheels of a bike that support to each other. When the two wheels are good, the bike will run well. Yet, when one of them is flat, the bike cannot move properly. This means that parents and teachers should work hand in hand for the children to reach the goal ${ }^{5}$.

\section{EHV: Developing the Self-Awareness and the School}

The construction of self-awareness at the Sathya Sai School Denpasar is aimed at establishing the foundation for developing humanity. It needs the cooperation of parents at homes and teachers at schools.

There are three strategies to be used in teaching EHV. First, it can be done by integrating the values into the curriculum. This means any lesson in the classrooms should teach the values and the values should ensoul all of them. When a teacher fails to teach them,

4 Jumsai Na Ayudhya, Art Ong, A Development of The Human Values Integrated Instructional Model Based on Intuitive Learning Concept .(Chulalongkon University, Bangkok, Thailand, 2003) p. 12-20

5 Marilyn Price-Mitchell, PhD, Self-Awareness: How Parents Foster Meaning and Purpose in Kids. This article is republished and updated with many new articles each year at RootsofAction.com. Copyright $2012-$ 2016 
he (she) is not a teacher but a cheater. Second, EHV is also possible by inserting them in the extracurriculum program, e.g. drama, discussion, musics, etc. Thirdly, EHV may be provided to the children at schools by teaching them directly, through some class activities, i.e.: (1) silent sitting or meditating. Yet before having the actvities at school all teachers should do them at homes with their own families; (2) praying and reciting holy verses; (3) group chanting; (4) story telling; and (5) role playing, etc. There should be remembered here that learning is the same as entering the uncomfort zone that is full of risk. A teacher is teaching because he (she) is being allowed by the students and not because he (she) is obtaining an authority by the institution. These strategies are such a construction that moves learning as an uncomfortable zone to be a comfortable zone.

At Sathya Sai School the EHV is not taught in a traditional way. When the students are doing silent sitting, for example, methaporical words in simple EHV philosophy are spoken and implanted. They can be also delivered through listening to particular songs, and let the children think deeply about the meanings. These are all expected to raise the spirit of the children to be positive. Another activity is named the morning circle. In this activity, the teacher is reminding the children to do good things as habit, either at homes, schools, or other places. And the last activity is having breakfast together. In it, the children are conditioned for learning to be patient, to keep clean, to share, and to be thankful.

Such constructive activities are not effective at all if they are done only at the school because of the limited school hours. The role of the parents at homes, especially the mothers, is wholly needed. This is the reason why the parenting program is considered important. It is supposed to build the parents'senses of belonging so that they are contributive to the EHV program and involved actively in concrete activities, e.g. preparing the meal and clean around the school area. When the parents understand correctly the EHV the self-awareness within the children will be definitely realized. Then, the children will become honest, independent, tough, and studious. In the end, it creates a good school atmosphere.

D.

Conclusion

The self-awareness of the students of Sathya Sai School has been developed through EHV program. The values, i.e. truth, right-conduct, peace, love, and non-violence are the main content of the program. The concepts are transformed into affirmative, habitual, and inspiring concrete activities that are supposed to be easily understood. Then they are programmed and modeled by the school teachers and the parents. The self-awareness provides the children with the competence for controlling their emotion, having the spirit to fight and be independent, either physically or mentally.

\section{E. Acknowledgements}

Great thanks are addressed to management of Denpasar Sathya Sai School and all of the organizers of GC-TALE 2017 due to the publication of this article. Many thanks for all of the important people who involved in the completion of this article. Without their guidance, supports, and advices, this article would never have been completed. Hopefully, it can give benefit for the readers.

\section{References}

Budiningsih, C. A. 2004. Pembelajaran Moral: Berpijak pada Karakteristik Siswa dan Budayanya. Jakarta: PT. Rineka Cipta. 
Bruce, Rita, 2003. Sathya Sai Parenting, Sri Sathya Sai Books and Publication Trust, Prasanthi Nilayam (India).

Bruce, Rita, 2005. Love of Conscience, Four Aspects of Human Natur, Sri Sathya Sai Books and Publication Trust, Prasanthi Nilayam (India).

Calhoun, C. 1993. Habitus, Field and Capital: The Question of Historical Specificity in Bordieu: Critical Perspectives. Cambridge: Polity Press

Catron, C.E. 2006. Early Childhood Curriculum: A Creative Play Model. Upper Saddle River, New Jersey: Pearson

Darmadi, H. 2006. Dasar Konsep Pendidikan Moral: Landasan Konsep Dasar dan Implementasi. Bandung: Alfabeta.

Jumsai Na Ayudhya, Art Ong, 2003. A Development of The Human Values Integrated Instructional Model Based on Intuitive Learning Concept . Chulalongkon University, Bangkok, Thailand.

Marilyn Price-Mitchell, PhD, Self-Awareness: How Parents Foster Meaning and Purpose in Kids. This article is republished and updated with many new articles each year at RootsofAction.com. Copyright 2012 - 2016

Maton. K. 2008. Habitus in Pierre Bordieu: Key Concepts. North Yorkshire: Acumen

Michal Einav ,2014. Perceptions about parents' relationship and parenting quality, attachment styles, and young adults'intimate expectations: A cluster analytic approach, The Journal of Psychology: Interdisciplinary and Applied, 148:4, 413-434.

Reed-Dannahay, D. 2005. Locating Bordieu. Indianapolis: Indiana University Press

Seetharam, Lakshmi and Kallidaikurichi Easwaran Seetharam, 2005, VIDYA: Values Integration for Developing Young Adults, Institute of Sathya Sai Education, San Pedro, Philippines.

Thomson. P. 2008. Field in Pierre Bordieu: Key Concepts. North Yorkshire: Acumen

Wardhani, W. D. L 2011. Konstruksi Identitas Kebangsaan dalam Pendidikan Kewarganegaraan di SD Kelas Awal. Thesis. Tidak Dipublikasikan.

Wortham, S.C. 2006. Early Childhood Curriculum: Developmental Bases for Learning and Teaching. Upper Sadle River, New Jersey: Pearson 